Cite this article: Louise Starkey (2020) A review of research exploring teacher preparation for the digital age, Cambridge Journal of Education, 50:1, 37-

56, DOI: $\underline{10.1080 / 0305764 X .2019 .1625867}$

\title{
A systematic review of research exploring teacher preparation for the
}

\section{Digital Age}

Louise Starkey.

\begin{abstract}
Digital technologies and the Internet are increasing in prominence in schooling systems. As schools and teaching evolve as a result of the integration of technologies teacher preparation will also change. This paper examines research exploring the preparation of teachers for the digital age through a systematic literature review of articles published between 2008 and 2018. The findings provide insight into what has and has not been studied across a range of literature and the alignment with the broader context of digital integration in schools. A focus on digital competencies was identified which was framed in three ways across the literature; generic digital competence, digital teaching competence and an emerging concept of professional digital competence. How student teachers learn to engage in the professional work of a teacher in a digitally infused education system should underpin future research. A model of professional digital competence is proposed.
\end{abstract}

\section{Introduction}

Digital technologies, including hardware, applications and supporting infrastructure, have been introduced into schooling systems globally which influences the work of a teacher. Initially, the introduction of generic digital technologies had limited usefulness and usability to meet the educational aims of teachers and schooling systems (Cuban, 2001; Davis, 1989). However, as the technology has advanced the usefulness and usability improved and management information systems began replacing some paper based or manual systems and practices within schools providing enhanced efficiency in areas such as timetabling and record keeping (Shah, 2014) and increased divergent options through the access of information and programmes for teaching (Albion, Tondeur, ForkoshBaruch \& Peeraer, 2015). Further advances have resulted in digital technologies that have the potential to change the work of an educator. For example, teachers and administrators with increased access to learning analytics can use digital tools to inform teaching and policy decisions (Collins \& Halverson, 2018), specialised applications are being designed with student learning and school context in mind (Voogt, Knezek, Christensen, \& Lai, 2018), school curriculum is evolving for the digital age (Starkey, 2016) and new forms of communication tools enable interaction and professional collaboration between teachers (Lips et al., 2017; Starkey \& Eppel, 2017). Digital technologies are predicted to become further embedded across the schooling sector and 
influence the work of teachers (Freeman, Adams Becker, Cummins, Davis, \& Hall Giesinger, 2017). Teachers entering the profession need to be prepared for schools and education systems that are becoming increasingly digitised.

When students graduate from an initial teacher education programme they should be confident in their ability to be a beginning teacher within the current and future context of schooling (Kaufman, 2015). The programmes that prepare teachers for their career should be informed by empirical evidence from research (Darling-Hammond, 2012). Research that explores the preparation of teachers for the digital age can be expected to change as digital technologies and infrastructure are introduced, integrated and then infused into schooling systems.

Previous literature reviews have explored aspects of teacher preparation including the pedagogical approaches to develop digital competencies (Røkenes \& Krumsvik, 2014), teacher education programmes preparing students for a knowledge society (Cochran-Smith et al., 2015) or models used within research (Voogt et al., 2013). The aim of this study is to answer the research question: What has been researched within studies examining the preparation of teachers for the digital age? The aim is to identify what research focus is needed for the future.

\section{Methodology}

A systematic approach was applied to locate articles reporting research about preparing teachers to be teachers in the digital age (Figure 1). Three education data bases, Education Source, A+ Education and Proquest Education (which includes ERIC) were searched using the keywords (initial teach* OR preservice teach* OR student teach*) AND (ICT OR digital OR computer) AND (program* OR course) across peer reviewed journal articles. The initial search was undertaken in the final week of January 2018 yielded 148 articles in Education source, 97 in Proquest and two in A+ Education. The second phase involved manually applying exclusion criteria by reviewing titles and abstracts. Included were journal articles that reported research about preparing students for general primary or secondary school teaching in the digital age. Excluded articles examined one aspect of teacher education such as subject specific preparation, the educational use of a particular software or hardware like e-portfolios, or using digital technology to teach a particular group of students like visually impaired or EFL students. The context of education and digital technology capability is changing rapidly therefore a time limitation of 2008-2018 was applied and the initial search was limited to peer reviewed journal articles. This resulted in 67 articles identified for possible inclusion. The reading of each complete article excluded a further 19 articles that did not report research or develop theory such as those that described programmes resulting in a total of 48 articles, of which one was a review of literature. 


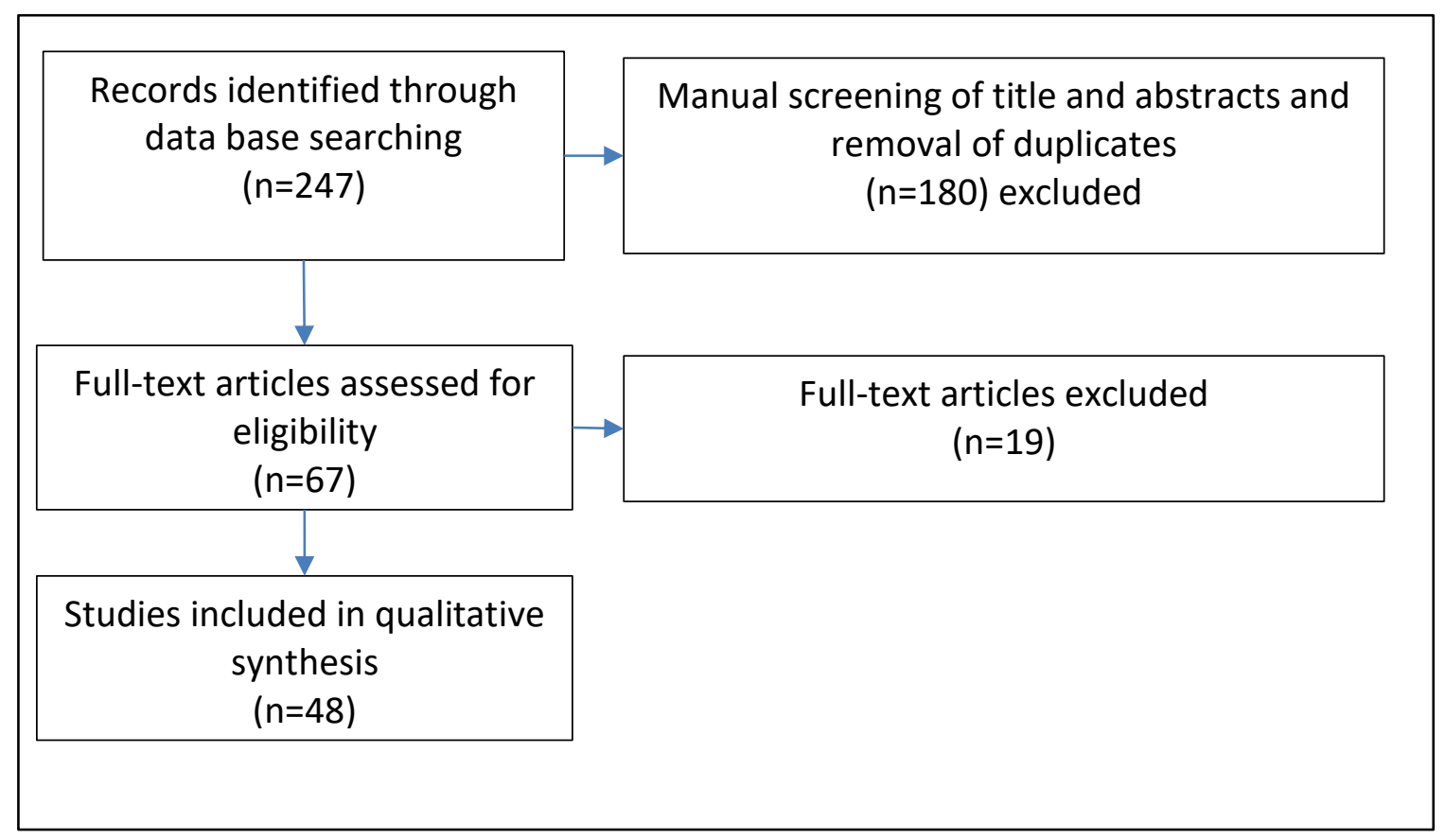

Figure 1. Article identification and selection summary.

The articles reviewed were analysed through NVivo 11 software. Each article was imported and coding nodes created as the question was asked:

What aspects of initial teacher preparation with regards to the digital age was examined in this article?

A thematic analysis was undertaken of the content of the articles guided by the methods outlined by Braun and Clark (2006) to identify latent themes. The initial coding nodes were developed further through the use of Nvivo text queries across the literature. For example, competence was a strong theme therefore a systematic search for 'competency' or synonyms of this term identified the extent of usage enabling an examination of how the concept was positioned within articles. Not all instances of a word appearing in an article warranted inclusion as part of a theme, as nodes and themes centred on what was being examined through research. Each theme was analysed to identify the patterns within. This involved an iterative process of multiple reading of each article to develop and test emerging patterns.

The total number of articles included in the review was 47 . The articles included provide a global perspective including; Australia (6), Belgium (4), Canada (2), Chile (1), China (1), Finland (2), Ghana (1), Netherlands (1), New Zealand (1), Norway (6), Rwanda (1), Singapore (4), Slovenia (1), Taiwan (1), Turkey (4), United Kingdom (2), USA (7), Vietnam (1), Zimbabwe (1) and one review of literature. The keywords used in the search for literature may have limited the articles that were identified for inclusion, however the number and global spread enabled analysis that provided a range research of initial teacher preparation for the digital age or ICT integration. In addition to the analysis using query and thematic node coding in Nvivo, a table was developed that summarised each article was developed. 


\section{Findings.}

Research in the past 10 years has examined student teachers, teacher educators and the initial teacher education programmes. Within these areas were themes of student teachers' digital competence, integration into teaching practice, personal characteristics, the pedagogical practices of teacher educators and programme design (Table 1).

\section{Student teachers' digital competence}

Student teachers' digital competence was a significant theme across the reviewed literature with 26 articles including the word competence directly or a synonym within the text more than 10 times. While competence was mentioned frequently across the literature, there was not one universal definition and it was not clearly defined in individual articles. The survey, interview questions or discussion section provided insight into what was meant by digital competence in individual articles. A limitation of the studies that examined digital competence was the extensive use of self-report methods and the lack of objective data which could have less subjective bias. A deductive analysis across the literature identified three implicit orientations of teacher digital competence; competence in the generic use of computers, integrating digital technologies into teaching practice and professional digital competence.

\section{Generic digital competence}

Generic digital competence includes skills that are not specific to teaching or the professional work of a teacher and was examined in 13 studies, synonymous with 'technological knowledge' in the TPaCK model (Mishra \& Koehler, 2006). However, the types of technological knowledge varied across the studies. Researchers explored student teachers' perception of their ability to carry out common computer functions such as manage online files (Guo, Dobson, \& Petrina, 2008; Maderick, Zhang, Hartley, \& Marchand, 2016), touch type (Hope \& Hunt, 2010), use presentation software such as Powerpoint, word-processing or image capture (Aslan \& Chang, 2017; Bratina, 2017; Gill \& Dalgarno, 2017; Guo et al., 2008; Hope \& Hunt, 2010; Jamieson-Proctor, Finger, \& Albion, 2010; Maderick et al., 2016), search the Internet (Aslan \& Chang, 2017; Gudmundsdottir \& Hatlevik, 2017; Guo et al., 2008; Mukama, 2009; Yeung, Lim, Tay, Lam-Chiang, \& Hui, 2012), use spreadsheets (Guo et al., 2008), online communication (Maderick et al., 2016; Yeung et al., 2012), or use simulations or software (Aslan \& Chang, 2017; Yeung et al., 2012). This range of skills could be generic knowledge for anyone using a computer for learning, working or managing everyday life in the 2010s and can be applied to teaching practice. The focus on these types of generic skills is relevant in a context where it is assumed that student teachers may not have these skills, which suggests those entering teaching have had limited experience of digital technology use. It is interesting to note that the research articles originate from a range of countries, not only developing countries. 
Table 1. Themes within the literature.

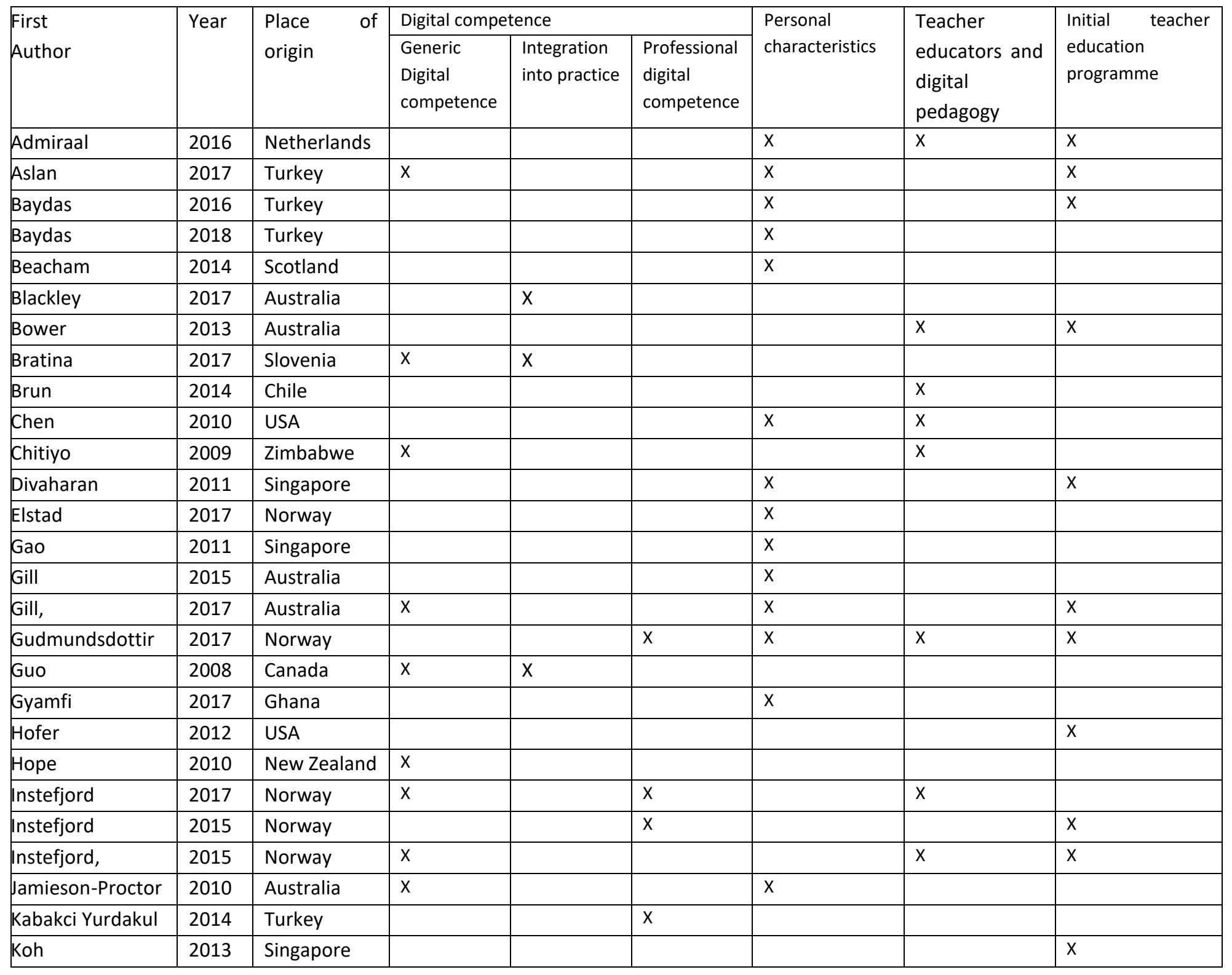




\begin{tabular}{|c|c|c|c|c|c|c|c|c|}
\hline \multirow{2}{*}{$\begin{array}{l}\text { First } \\
\text { Author }\end{array}$} & \multirow[t]{2}{*}{ Year } & \multirow{2}{*}{$\begin{array}{l}\text { Place of } \\
\text { origin }\end{array}$} & \multicolumn{3}{|c|}{ Digital competence } & \multirow{2}{*}{$\begin{array}{l}\text { Personal } \\
\text { characteristics }\end{array}$} & \multirow{2}{*}{$\begin{array}{l}\text { Teacher } \\
\text { educators and } \\
\text { digital } \\
\text { pedagogy }\end{array}$} & \multirow{2}{*}{$\begin{array}{l}\text { Initial teacher } \\
\text { education } \\
\text { programme }\end{array}$} \\
\hline & & & $\begin{array}{l}\text { Generic } \\
\text { Digital } \\
\text { competence }\end{array}$ & $\begin{array}{l}\text { Integration } \\
\text { into practice }\end{array}$ & $\begin{array}{l}\text { Professional } \\
\text { digital } \\
\text { competence }\end{array}$ & & & \\
\hline Krumsvik & 2012 & Norway & & & & & $x$ & \\
\hline Kumar & 2011 & USA & $x$ & $x$ & & $x$ & & \\
\hline Liu & 2015 & Taiwan & & & & $x$ & & \\
\hline Martinovic & 2012 & Canada & & & & $x$ & & \\
\hline Mukama & 2009 & Rwanda & $x$ & $x$ & & & & \\
\hline Peeraer & 2011 & Vietnam & & & & & $x$ & \\
\hline Polly & 2010 & USA & & & & $x$ & & \\
\hline Reyes & 2017 & Australia & & & & & $X$ & \\
\hline Tondeur & 2017 & Belgium & & & $x$ & & $x$ & \\
\hline Tondeur & 2016 & Belgium & & & & $x$ & & $x$ \\
\hline Tondeur & 2013 & Belgium & & & & & & $x$ \\
\hline Turvey & 2008 & England & & & $x$ & & $x$ & \\
\hline Urbani & 2017 & USA & & & & & $x$ & $x$ \\
\hline Valtonen & 2018 & Finland & $x$ & & & $x$ & & \\
\hline Valtonen & 2015 & Finland & & & & $x$ & & \\
\hline Xiong & 2015 & China & & & & & & $x$ \\
\hline Yeung & 2012 & Singapore & $x$ & & & $x$ & & \\
\hline
\end{tabular}


Generic digital competence includes the ability to use creative and collaborative technologies which could be applied to developing learning resources. Researchers explored student teachers perceived ability in multimedia creative competencies such as video editing (Aslan \& Chang, 2017; Bratina, 2017; Jamieson-Proctor et al., 2010; Yeung et al., 2012), online drawing or image development (Hope \& Hunt, 2010) web development skills (Kumar \& Vigil, 2011) and creating video or music (Guo et al., 2008). In addition, one study included a focus on digital competence in the use of web2.0 tools including blogs, wikis, podcasts and electronic portfolios (Kumar \& Vigil, 2011). This research examined creative and collaborative digital competence of student teachers with the assumption that such skills could or would be applied to teaching.

The ability of student teachers to use computer hardware was a third aspect of generic digital competence included in the reviewed literature. Specific tools identified include use of a data show (Aslan \& Chang, 2017; Martinovic \& Zhang, 2012), cell phone, web camera, speakers, music player, laptop or printer (Martinovic \& Zhang, 2012). In addition, student teachers' ability to use interactive whiteboards was a specified competency in two studies (Instefjord \& Munthe, 2017; Martinovic \& Zhang, 2012). Researching the ability of student teachers to use digital tools may be more relevant when the hardware is new and teacher educators are unfamiliar with incorporating the technology into their programmes. For example, being able to use a data show could be a key skill to teach in initial teacher education programmes when whiteboards are replaced with screens and research can inform the programmes and pedagogy.

The reason for focusing on generic digital competencies is clarified in an article that provides a specific definition; 'The term digital competence herein shall be construed and limited to mean having the skill, ability, and knowledge to successfully use computers, their related applications, and software in the practice of teaching and education' (Maderick et al, 2016, p.329). This broad definition could encompass a wide range of applications in the work of a teacher. However, the reported study examined student teachers' reported knowledge of word processing, Web 2.0, e-mail/Internet, presentations, spreadsheets and databases. Thus generic computing knowledge that could be applied to the practice of teaching was explored.

\section{Digital teaching competence}

A second type of digital competence in the examined literature is the ability to integrate digital technology into teaching practice. Three aspects were identified including; integrate digital tools into existing pedagogical practice, to consider decisions critically, and to teach students who are using technologies for learning.

Integrating digital tools into existing pedagogical practice includes the use of blogs, Facebook, podcasting or other communication tools in teaching and learning activities (Kabakci Yurdakul \& Çoklar, 2014) or developing and using digital assessments (Gudmundsdottir \& Hatlevik, 2017; Kabakci Yurdakul \& Çoklar, 2014). Digital competencies is framed in these research articles as being able to replace or enhance established teaching practices with digital tools. 
The technological, pedagogical and content knowledge (TPaCK) model provides a theoretical framework for ICT integration into teaching practice (Mishra \& Koehler, 2006). The TPaCK model underpinned 20 studies that explored generic digital competence and the integration of digital technologies into teaching practice. For example, the integration into teaching is positioned as the intersection of technological, pedagogical and content knowledge in the TPaCK model (Polly, Mims, Shepherd, \& Inan, 2010). This includes broad competence in the ability to select, critique and use ICT applications in teaching (Ping, Tan, Longlong, Wong, \& Choy, 2011; Tondeur, Scherer, Siddiq, \& Baran, 2017; Valtonen, Kukkonen, Kontkanen, Mäkitalo-Siegl, \& Sointu, 2018) and has been researched in terms of student teacher development across a programme (Gill, Dalgarno, \& Carlson, 2015) and integration as they begin teaching (Ping et al., 2011).

A review of literature that explored the theoretical basis and practical use of TPaCK found differing understandings of both the model and technological knowledge and limited exploration of TPaCK in subject domains (Voogt, Fisser, Pareja Roblin, Tondeur, \& van Braak, 2013). This was reflected within the reviewed research. For example, content knowledge was rarely specified, technological knowledge might mean how to use a PowerPoint or an interactive whiteboard and pedagogical knowledge ranged from how to use technology to replace learning resources or tools to new digital pedagogies or student engagement. The research articles exploring the intersection of the three types of knowledge appears to focus on preparing teacher to teach in a context where digital technologies are embedded in the teaching and learning context, with both the teacher and student using technologies (for example, Tondeur, Aesaert, et al., 2017).

The examination of the student teachers' ability to consider a teaching aim and how digital technology fits with this suggests critical integration. Instefjord (2015) defined this digital competence as the 'knowledge, skills and attitudes required in order to use technology critically and reflectively in the process of building new knowledge'(p155). This contrasts with the integration of ICT as a replacement of existing practice.

One further aspect of digital competence in teaching practice in the research literature is being able to teach children who are using technologies for learning. For example, being able to organise or manage the environment in an appropriate way to use technology (Elstad \& Christophersen, 2017; Kabakci Yurdakul \& Çoklar, 2014; Tondeur, Aesaert, et al., 2017) or supporting learners to use ICT for learning critically, ethically and creatively (Tondeur, Aesaert, et al., 2017). Pedagogical approaches examined include; student teachers becoming competent in communicating online with children about their learning progress (Tondeur, Aesaert, et al., 2017; Turvey, 2008), developing learner's collaboration skills (Gudmundsdottir \& Hatlevik, 2017), student-centred learning (Chen, 2010) or learning how to 'flip' learning through the use of video and online resources (Admiraal et al., 2016). Research that examines competence in teaching learners using technology considers different competencies to those used for teaching with digital technologies. 
The integration of ICT in teaching practices include three different types of competencies in the literature. The first was being able to use particular technologies as a teacher, the second is being able to select and critique which technology to use for a specific teaching purpose, and the third is being able to plan and teach students who are learning through and with digital tools.

\section{Professional digital competence}

A third category of digital competence examined in this selection of literature is professional digital competence. This concept is emerging from the Norwegian context. Instefjord and Munthe (2015) outlined a model of professional digital competence that includes three aspects: technological proficiency, pedagogical compatibility and social awareness. Social awareness being the teacher's understanding of and ability to negotiate the social aspects of school culture (p80). It is underpinned by the notion that a teacher needs to be able to negotiate and problem solve to successfully integrate digital technology into their teaching and learning. This model draws on prior research to emphasise digital competence in the technical skills and ability to integrate digital tools and software into teaching practice. The same authors then expanded this definition in a later article to 'being able to integrate and use technology for educational purposes through a set of generic skills suitable for all situations, both personal and professional, as well as specific teaching-profession skills' (Instefjord \& Munthe, 2017, p. 37) thus taking it beyond teaching to the broader roles of a teacher. They conclude their research noting that professional digital competence needs to be clearly defined.

The term is used again by Gudmunsdottir and Hatlevik (2017). Professional digital competence in this study included a range of aspects of a teacher's job that can involve the use of digital tools including assessment, administration of data and communicating. This study also asked the student teachers about monitoring the learning environment when learners are using ICT.

The notion of professional digital competence is further expanded and at the forefront of an ICT competency framework developed by Tondeur, Aesaert et al (2017). The framework was designed around three domains in the teaching profession: (1) instructional and pedagogical tasks, (2) professional development and (3) the school in a broader context (p465). The notion of professional digital competence could be further expanded to be inclusive of all aspects of being a teacher in schooling contexts and education systems where digital technologies are embedded.

\section{Student teacher personal characteristics}

The reviewed articles not only explore digital competence, but also research beliefs, confidence or efficacy that student teachers have regarding their use of ICT. This was framed in six ways across the literature reviewed including; exploring how confident student teachers were in using ICT to inform the design of education programmes (Jamieson-Proctor et al., 2010), student teacher confidence or efficacy compared with use (Yeung et al., 2012) or intentions to use ICT in teaching (Baydas \& Goktas, 2016; 
Baydas \& Yilmaz, 2018; Gyamfi, 2017; Valtonen et al., 2015), how confidence, beliefs, attitudes or efficacy influence technology (Aslan \& Chang, 2017; Chen, 2010; Tondeur, Scherer, et al., 2017), how self-efficacy in other aspects of teaching influences use (Elstad \& Christophersen, 2017), attitudes and beliefs towards using ICT within inclusive education and practice (Beacham \& McIntosh, 2014), and how self-efficacy relates to the perceived quality of ITE with regards to digital competence (Gudmundsdottir \& Hatlevik, 2017). This range reflects different aspects of learning to teach in an emerging digitised system. As digital technologies become embedded and considered 'normal practice' within the work of teachers, then digital confidence or efficacy will have less emphasis in research or be subsumed into general research on educator motivation and efficacy.

Aligned with research exploring beliefs, confidence and efficacy, are studies that explore specific characteristics of the student teachers such as digital natives, experience before studying to be a teacher and motivation to use ICT.

Whether student teachers have the disposition to use ICT was a focus in two studies. Mukumba (2009) identified three dispositions to the use of ICT in student teachers' everyday learning practice. These included passive, active and reluctant users. Tondeur, Scherer, et al. (2017) developed student teacher profiles based on their motivation to integrate ICT into their classroom practice, noting that some student teachers are motivated to integrate ICT and others not. While the two studies focus on a similar idea, one is centred on generic use of ICT for learning and the other on integration of ICT into teaching.

Four articles reported research that was underpinned or explored the notion of digital natives. Guo, Dobson and Petrina (2008) examined the intersection of age and ICT competency and concluded that age does not influence ICT competency. This compared with a study exploring the current generation of student teachers' perception of appealing multimedia study (Bratina, 2017). The third study examined how the 'Net Generation' transfers their generic digital capability into educational environments (Kumar \& Vigil, 2011). A fourth study explored the perceptions of students who used laptops at school and are subsequently studying to be teachers themselves (Blackley \& Walker, 2017). Therefore two different ways of considering digital natives are included in the reviewed literature. One that explores the notion of digital native and another that uses the notion to explore how current student teachers perceive or integrate their existing digital knowledge into their teaching.

\section{Teacher educators}

Teacher educators' generic digital competence in the use of technology, their ability to integrate technology to teach student teachers how to teach in a digital context and the pedagogical approaches used to teach student teachers was researched in the reviewed literature. 


\section{Digital competence}

The examination of teacher educators appeared to mirror that of student teachers with research exploring generic digital competence and the integration of technology in their teaching practice. Teacher educators' generic digital competence was examined in different ways as an important precondition to digital integration. This included an exploration of perceptions of digital competency amongst teacher educators (Instefjord, 2015) assessing the generic competence or confidence of teacher educators to integrate technology into their teaching practice (Brun \& Hinostroza, 2014; Chitiyo \& Harmon, 2009; Peeraer \& Van Petegem, 2011) and an examination of a programme to develop teacher educators' ICT capabilities so they could integrate digital technologies into their teaching practice and model approaches to student teachers (Bower, Highfield, Furney, \& Mowbray, 2013). Two further studies explored how teacher educators integrate digital technologies into their teaching practice (Brun \& Hinostroza, 2014; Reyes, Reading, Doyle, \& Gregory, 2017) and one study explored how a collaboration between preservice teachers and mentor teachers can develop their TPaCK (Liu, Tsai \&Huang, 2015).

Teacher educators' ability to prepare students to integrate technology into their practice was the focus in a study by Instefjord and Munthe (2017). Digital competence was measured using six self-report indicators; educating students in the use of digital tools and ethical issues related to use of social media, being a role model, knowing how to use digital tools to promote learning, competence in the use of interactive whiteboards and digital tools for assessment purposes. These indicators place an emphasis on preparing teachers to integrate digital technologies into their teaching practice and educating their students for a digital future.

Teacher educators' digital competence was examined in the reviewed articles. Krumsvik drew on research and context to develop a digital competence model for teacher educators (2012). He defined teacher educator competence as 'the individual teacher educator's proficiency in using ICT in teacher education with good pedagogical judgement and his/her awareness of its implications for learning strategies and the digital bildung of student teachers" (2012, p. 466). Bildung being a process of personal and philosophical maturation. Thus it is framed as the critical and informed use of technology to teach student teachers to integrate technology. A broader view of teacher educator professional digital competence that included aspects beyond teaching was not identified in the selected literature.

\section{Pedagogical approaches}

Eight pedagogical approaches within teacher education programmes were identified in a review of literature that examined the development of digital competence in student teachers at secondary school level. These included: collaboration, metacognition, blending, modelling, authentic learning, student-active learning, assessment, and bridging theory/practice gap (Røkenes \& Krumsvik, 2014). The pedagogical approaches explored in the research articles reflect beliefs about effective pedagogical practices. 
Teacher educators being able to model the use of digital technology to student teachers was specifically discussed in some of the studies that explored teacher educator use of ICT (For example, Bower, Highfield, Furney, \& Mowbray, 2013; Instefjord \& Munthe, 2017; Urbani, Roshandel, Michaels, \& Truesdell, 2017). Admiraal et al (2016) concluded in their study that teacher educators need to be role models, without an explanation of why role modelling is a good pedagogical approach. However, three reasons for role modelling are provided across the literature. Gill and Dalgarno (2017) state that it provides student teachers with a learner's perspective. Tondeur, Roblin, van Braak, Voogt and Prestidge (2016) suggest that teacher educators' modelling technology use are an important motivator for beginning teachers to use technology in their own teaching, while acknowledging that field experiences are the critical factor influencing practice. Røkenes and Krumsvik (2011) conclude that modelling is a good method to introduce student teachers to a digital tool, but hands on learning is required to make use of ICT in their teaching practice. Thus it may be that while some researchers assume that role modelling is a useful pedagogical approach when student teachers are unfamiliar with learning with digital technology, it may be of limited value unless it is one stage within approximations of practice, where students are purposefully scaffolded from using digital tools to being able to apply tools within their teaching practice in a classroom context (Grossman et al. 2009).

\section{Initial teacher education programme}

The third area of research within the reviewed literature centred on the initial teacher education programme; the design of programmes, student learning within specific programmes and the connection between design and learning.

The development of different types of digital competencies was central across this focus. How digital competence is positioned in curriculum documents was explored by Instefjord \& Munthe (Instefjord \& Munthe, 2015). This contrasts to research that examined student teacher learning through their initial teacher education programme. For example, how student teachers develop TPaCK over their initial teacher education programme (Gill \& Dalgarno, 2017; Hofer \& Grandgenett, 2012; Shinas, KarchmerKlein, Mouza, Yilmaz-Ozden, \& J. Glutting, 2015) and the development of student teachers' technology- enabled learning design thinking (M. Bower et al., 2013). These studies focused on how programmes prepared teachers to be able to teach using digital technologies.

The intersection of programme design and student teachers' learning has the potential to identify high leverage practices in initial teacher education. Studies exploring this intersection included; how initial teacher education programmes develop student teacher digital competence (Røkenes \& Krumsvik, 2014; Urbani et al., 2017), how aspects of a programme influence student teachers' intention to use ICT (Aslan \& Chang, 2017; Baydas \& Goktas, 2016) how teacher education institutions develop the ability to integrate digital technologies into their teaching (Instefjord, 2015; Tondeur, Roblin, van Braak, Fisser, \& Voogt, 2013), and the connection between beginning teachers' technology uses and their initial teacher education programmes (Tondeur et al., 2016). 
Indirect studies of the intersection of student learning and programme design were identified in two further research agendas, one that examined how curriculum leadership influences the development of student TPaCK capabilities (Xiong \& Lim, 2015), while the second focused on how student teachers perceive the quality of the ITE programmes related to the development of their digital competence (Gudmundsdottir \& Hatlevik, 2017; Koh, Woo, \& Lim, 2013). The high leverage practices in these examples focus on student teachers developing generic digital competence and integration of technology into teaching. Initial teacher education programme research mirrors the research exploring student teacher and teacher educators' competence with a focus on digital competencies.

Research examining initial teacher preparation for a digital age have focused on three areas. First area are student teachers' competence, confidence, beliefs, personal characteristics or dispositions. The second area has been the teacher educators' digital competence and pedagogical approaches and the third area is the initial teacher education programmes; the design, student learning within specific programmes and the connection between design and learning. The theme of digital competence was central across the three areas and included three broad interpretations; generic digital competence, competence to integrate technologies into teaching practice and an emerging area of professional digital competence.

\section{Discussion}

Digital competence was a dominant research focus across the reviewed literature. However, three interpretations of digital competence were identified; generic digital competence, competence to integrate technologies into teaching practice and professional digital competence. The positioning of digital competencies in the articles represents differences in how research was framed and what was being examined. The differences appear to align across three different phases of digital integration; the introduction of digital tools to schooling contexts, the integration into existing systems and practices and the infusion across the work of the teacher.

Researching generic digital competence can provide insight into a context where digital technologies are being introduced. The student teachers, teacher educators and schools have limited or variable experience of using digital technology and the initial teacher education programmes aim to teach students to be able to use computers (For example, Maderick et al, 2016). The beginning teachers and teacher educators' educational technology use is predominantly through generic software for presentation and communication purposes. This research examines whether teachers or teacher educators believe they have the ability to use certain technologies, not the educational uses of technology. Developing expertise in generic competencies can occur when technology is embedded in the broader educational and societal context that student teachers and teacher educators have experienced. If those entering the teaching profession have not learnt to use communication and presentation technologies these generic competencies may need to be explicitly taught in the programme (for example, Shinas et al., 2015). Research into generic competencies can provide insight into the broader 
context of digital skills educators have but such skills will change over time and the research needs to explicitly identify why the particular skills are important for learning to be a teacher or teaching teachers to teach.

The notion of the digital native and digital immigrant (Prensky, 2001) has been a rhetoric within the field of education suggesting that schools and teachers were somehow failing the younger generation in the programmes they were offering particularly as digital tools are introduced into schooling. While evidence does not support generational differences in using learning technology (Margaryan, Littlejohn, \& Vojt, 2011), the notion appears to have influenced the research agenda directly through studies that explore teacher age with the assumption that younger are more digitally competent and indirectly through focusing on generic digital competence of student teachers and teacher educators rather than the application of the skills in their use of digital technologies for teaching.

The second interpretation of digital competence focused on the ability to integrate technology into teaching practice which aligns with the second phase of digital integration. This encompasses three dimensions; the ability to teach using digital technology, to critically evaluate teaching decisions and to teach students who are using digital technology. This research focus reflects a context where schools have technology available for teachers to use in the classrooms, therefore the initial teacher education institutions are preparing student teachers to be able to integrate digital technologies into their practice. Within this can be a range of contexts from schooling systems with minimal access to technologies to schools with reliable fast broadband access where each child has a device they use for learning, but for each of these dimensions the focus is on integrating digital technologies into teaching and learning (Figure 2).
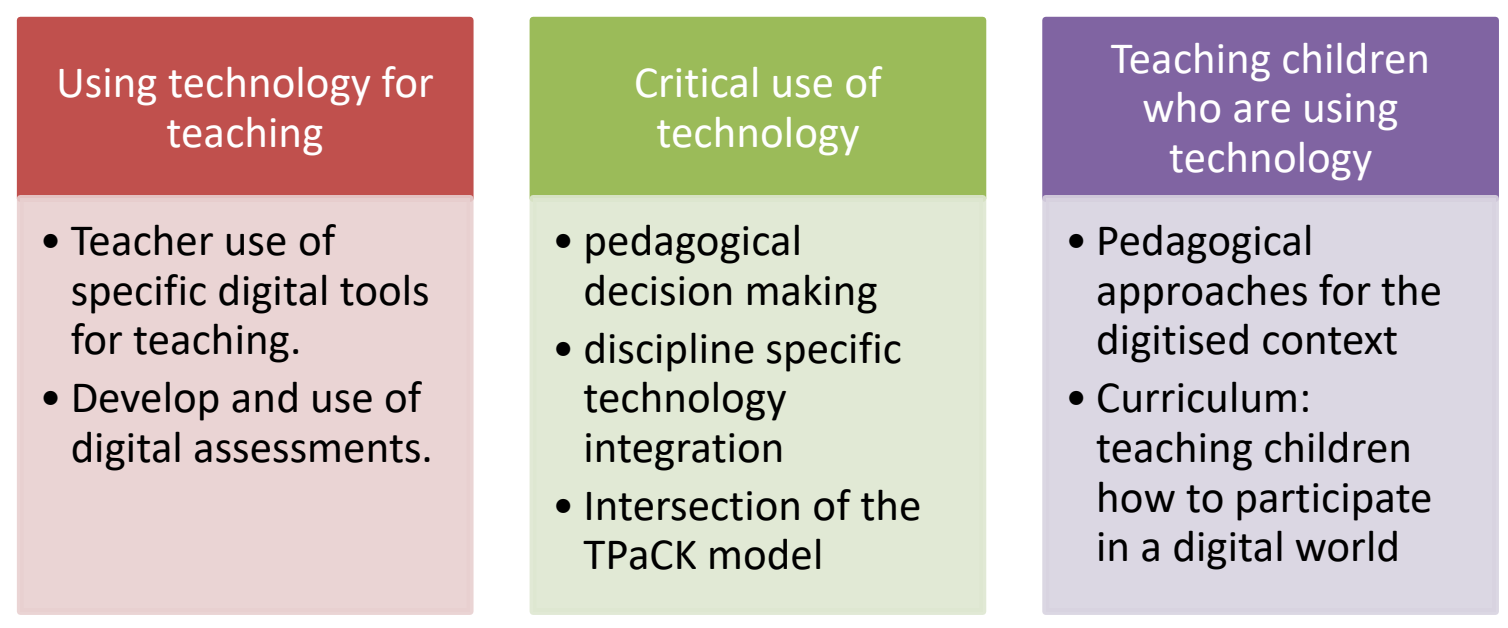

Figure 2. Three dimensions of integration of technology into teaching practices

Researchers exploring the use of technologies for teaching focused on whether student teachers use specific digital tools in their teaching practice and the development and integration of digital assessment tools. Evaluating whether student teachers are using technology in their teaching suggests a context where technology is integrated but not 
embedded within classroom practices, if it is usual practice for teachers to teach and assess using digital technology such research measurements would be redundant like measuring whether student teachers used a whiteboard 20 years ago. However, research evaluating the use of digital and assessment tools and identifying effective ways for student teachers to master their use could inform future teacher education programmes.

Research exploring the critical use of technology for teaching is underpinned by the notion of teacher agency through pedagogical decision making in initial teacher education (Loughran, Keast, \& Cooper, 2016). This aligns with the research exploring teacher decisions at the intersection of technological, pedagogical and content knowledge in the TPaCK model (Voogt et al., 2013). In addition, knowledge of subject specific technologies or uses of digital tools is an aspect of thinking critically about the use of technology which is at the intersection of content and technological knowledge and the first stage of pedagogical reasoning model (Starkey, 2010). For example, teaching about the use of GIS in geography, or developing the digital musician in music education. Discipline specific examples were not identified in the reviewed literature which may be due to the generic search terms used and exclusion criteria or this type of integration is not yet occurring widely.

The third dimension of integration, preparing teachers to be able to teach children who are using technology, suggests a context where infrastructure is sufficiently integrated for widespread access to digital technologies. In the reviewed literature this included exploring pedagogical approaches such as communicating online (Tondeur, Aesaert, et al., 2017; Turvey, 2008), developing collaborative skills (Gudmundsdottir \& Hatlevik, 2017), student-centred learning (Chen, 2010), and flipped learning (Admiraal et al., 2016). Teaching children or young people who are living in a digital world includes preparing them for their future participation in a digital society, teaching them to be digitally competent and responsible within the online world (Starkey, 2016). However, preparing teachers to teach a curriculum for a digital age was not identified in the reviewed literature which may reflect the dominant focus on competencies around the physical use of digital tools and pedagogies in research.

The third view of digital competence broadens the concept beyond the integration of technologies for teaching and learning. Professional digital competence has been identified in the literature but was not clearly defined. It aligns with a context of digitally infused education systems where digital technologies are embedded across everyday aspects of teachers work. In an infused system digital technologies such as data analytics (Williamson, 2017), information communication technology, administration software, Internet of Things and educational technology underpin processes and practices within a school (Freeman et al., 2017). The work of the teacher is influenced by the systems and pedagogies of the schools they teach in and teacher education programmes prepare teachers for this context. Therefore, teachers entering a digitally infused schooling system require professional digital competence.

Professional digital competence is the ability of the teacher to work in the context of a digitised school and education system. This includes mastering a range of teacher competencies such as being able to teach in a digitally infused context, manage digital 
learning environments and carry out the broader professional work of being a teacher (Figure 3).

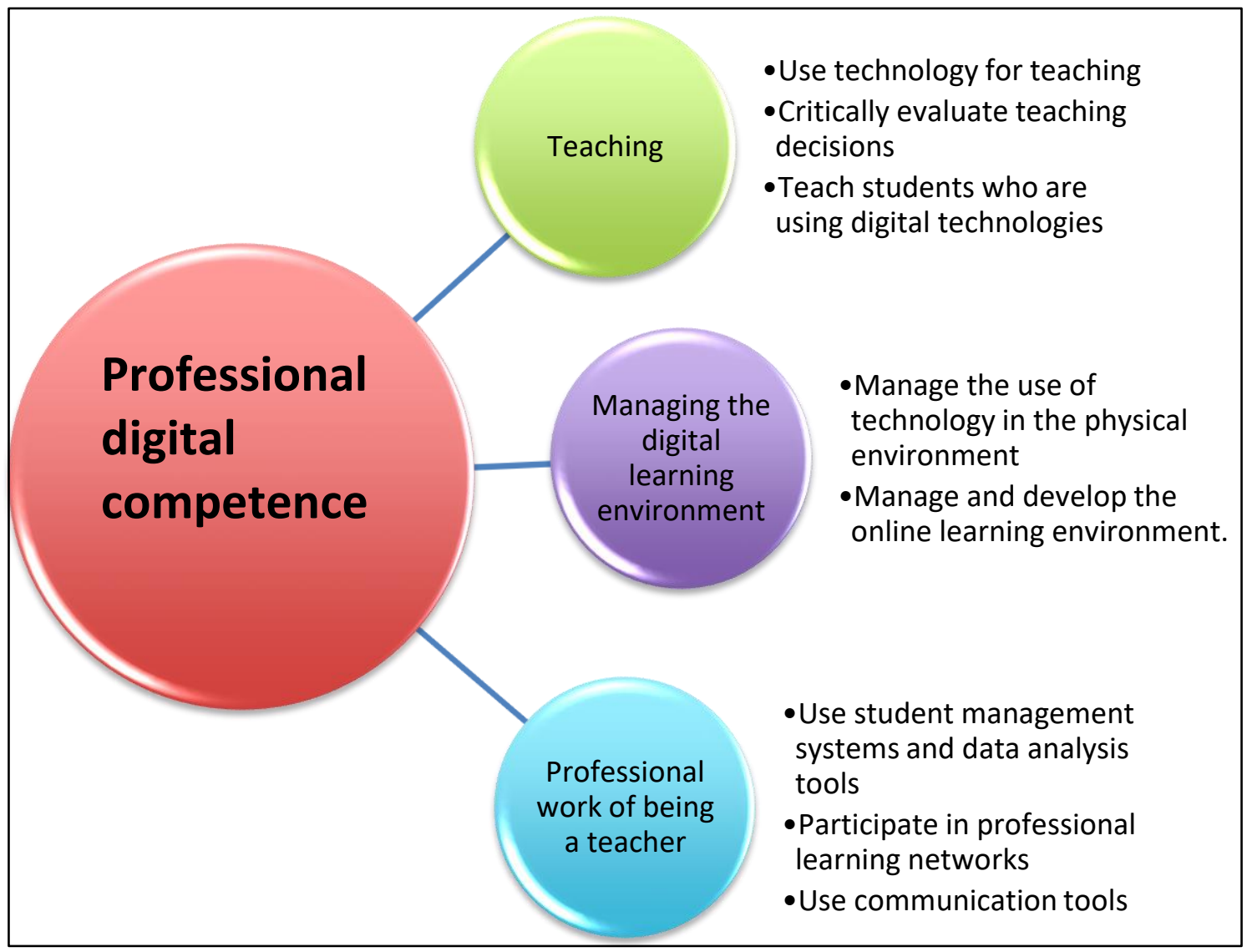

Figure 3. Professional digital competence for digitally infused education systems.

While researchers are exploring how to integrate technologies into teaching practice, how teachers learn to manage the digital learning environment was also a feature of the reviewed literature. Teachers are using learning management systems and educational programmes to orchestrate student learning. This involves aspects that mirror the physical space such as managing student interactions, online resources, student motivation and assessment. Managing the digital learning environment has two aspects: managing the use of devices within the physical learning environment, which was included in six studies (Elstad \& Christophersen, 2017; Kabakci Yurdakul \& Çoklar, 2014; Tondeur, Aesaert, et al., 2017), the second aspect is managing the online learning environment, a focus that was evident in one study (Turvey, 2008). The digital learning environment has features that do not mirror the physical environment such as the use of learning management systems which enable students to access learning activities and teachers beyond school (Starkey \& Eppel, 2017). The development and management of digital resources was not identified directly in the reviewed literature as a focus for study although generic skills create digital resources were measured (for example, Kumar \& Vigil, 2011). There is the opportunity for initial teacher education research to examine how student teachers learn to manage digital learning environments.

The third aspect of professional digital competencies are the ability to participate in the professional work of being a teacher in a digitally infused education system. 
Underpinning this notion of the professional work of a teacher in a digital age are the opportunities to connect across networks and accessing research and data as a basis for professional learning. This involves participating in online communities of learning, engaging in formal and informal teacher led professional learning, and communicating with parents and the broader the school community (Tondeur, Aesaert et al, 2017). Research, data analytics and information about students available through student management systems enable teachers to carry out inquiries to inform their teaching and enable them to contribute to building and improving the knowledge base of their profession as advocated by Cochran-Smith \& Lytle (2009), this includes the use of digital tools to analyse assessment data. How student teachers develop professional digital competence for a digitally infused education system should underpin future research.

The three types of digital competencies identified through this review provide a framework for considering the context of research into initial teacher education in a digital age. There is overlap between the competencies; generic digital competencies include skills needed to integrate digital technologies into teaching practice and professional digital competence includes the ability to integrate digital technologies into practice. However, while they have similarities, they each align with a different ITE programme aim. (Figure 4).

\begin{tabular}{|c|c|c|c|}
\hline & $\begin{array}{l}\text { Generic digital } \\
\text { competencies }\end{array}$ & $\begin{array}{l}\text { Digital teaching } \\
\text { competencies }\end{array}$ & $\begin{array}{l}\text { Professional digital } \\
\text { competencies }\end{array}$ \\
\hline \multirow[t]{3}{*}{$\begin{array}{l}\text { Competencies } \\
\text { examined. }\end{array}$} & \multirow{3}{*}{$\begin{array}{l}\text { Use presentation, } \\
\text { creative, } \\
\text { collaborative and } \\
\text { communication } \\
\text { software and } \\
\text { Use hardware such } \\
\text { as datashows, } \\
\text { cameras and } \\
\text { printers }\end{array}$} & $\begin{array}{l}\text { Teach using digital } \\
\text { technologies }\end{array}$ & $\begin{array}{l}\text { Teach using digital } \\
\text { technologies }\end{array}$ \\
\hline & & $\begin{array}{l}\text { Evaluate teaching } \\
\text { decisions critically }\end{array}$ & $\begin{array}{l}\text { Manage digital } \\
\text { learning } \\
\text { environments }\end{array}$ \\
\hline & & $\begin{array}{l}\text { Teach students } \\
\text { who are using } \\
\text { digital technology }\end{array}$ & $\begin{array}{l}\text { Use systems and } \\
\text { tools in the } \\
\text { professional work } \\
\text { as a teacher. }\end{array}$ \\
\hline $\begin{array}{l}\text { ITE programme } \\
\text { aim. } \\
\text { Teachers } \quad \text { to } \\
\text { develop: }\end{array}$ & $\begin{array}{l}\text { Technical } \\
\text { knowledge to use } \\
\text { technologies for } \\
\text { teaching. }\end{array}$ & $\begin{array}{l}\text { Knowledge of how } \\
\text { to apply digital } \\
\text { technologies to } \\
\text { replace or enhance } \\
\text { established } \\
\text { teaching practices. }\end{array}$ & $\begin{array}{l}\text { Knowledge of how } \\
\text { to be a teacher in a } \\
\text { digitally infused } \\
\text { schooling system }\end{array}$ \\
\hline $\begin{array}{l}\text { Educational } \\
\text { context. }\end{array}$ & $\begin{array}{l}\text { Introduction of } \\
\text { digital } \\
\text { technologies. }\end{array}$ & $\begin{array}{l}\text { Integration of } \\
\text { digital technologies } \\
\text { into teaching } \\
\text { programmes }\end{array}$ & $\begin{array}{l}\text { Infusion of digital } \\
\text { technologies across } \\
\text { the work of a } \\
\text { teacher. }\end{array}$ \\
\hline ITE programme & $\begin{array}{l}\text { Course on how to } \\
\text { use digital } \\
\text { technologies }\end{array}$ & $\begin{array}{l}\text { Course on how to } \\
\text { teach with digital } \\
\text { technologies }\end{array}$ & $\begin{array}{l}\text { Digital technology } \\
\text { use infused across } \\
\text { the programme }\end{array}$ \\
\hline
\end{tabular}

Figure 4. Digital competencies in context. 
Research exploring where and how learning should occur within initial teacher education programmes appears to be aligned with the type of digital competencies being prioritised. Perspectives ranged from having standalone courses with no link to in school practice to teach generic digital competencies to a view that programmes should have digital competencies infused across courses. For research exploring individual aspects of TPaCK or technological knowledge, a standalone course teaching generic digital competencies was suggested (for example, Shinas et al., 2015). Where the context is the integration of technology into teaching practice there may be an expectation that a teacher education programme includes a course on technology integration, this contrasts to other researchers whose research suggests a belief that pedagogical tools for teaching and learning should be subject specific (Baydas \& Goktas, 2016) or integrated in all subjects and experiences in the teacher education programmes (for example, Instefjord \& Munthe, 2017). If the aim is to develop professional digital competence in a context where digital technologies are infused across the work of a teacher then the competencies would be integrated across the programme, including course work and practice within schools, and research would explore or evaluate this integration. Future focused research programmes should develop understanding of how student teachers can be prepared for digitally infused schooling contexts (Voogt et al., 2013) through the development of professional digital competencies.

\section{Conclusion}

Initial teacher education is the process of preparing teachers for the schooling context that they will enter. As the schooling context changes when digital technologies are introduced, integrated and infused within the education system, initial teacher education programmes change as does the research that informs programmes and practices. The agenda underpinning initial teacher education research is evolving as digital tools are introduced, integrated or infused into schooling and education systems.

The research in the reviewed articles examined digital competence which was framed in three different ways; generic digital competencies, digital teaching competencies and professional digital competencies. Generic digital competencies align with a context where digital tools are being introduced to the system and researchers are exploring the skills that student teachers and teacher educators believe they have. Digital teaching competencies focus on a context of integration, preparing teachers to be able to use technologies for teaching, evaluate use critically and to teach children or young people who are using digital devices for learning. A third type of competence is emerging in the literature. In this article the notion of professional digital competence has been developed and defined as the ability of the teacher to work in the context of a digitally infused schooling education system, including teaching, manage the digital learning environment and the professional work of being a teacher. Future research agenda should further examine professional digital competence within initial teacher education. 


\section{References}

Admiraal, W., van Vugt, F., Kranenburg, F., Koster, B., Smit, B., Weijers, S., \& Lockhorst, D. (2016). Preparing pre-service teachers to integrate technology into $\mathrm{K}-12$ instruction: evaluation of a technology-infused approach. Technology, pedagogy and education, 26(1), 105-120. doi:10.1080/1475939x.2016.1163283

Aslan, A., \& Chang, Z. (2017). Investigating variables predicting Turkish pre-service teachers' integration of ICT into teaching practices. British Journal of Educational Technology, 48(2), 552-570. doi:10.1111/bjet.12437

Baydas, O., \& Goktas, Y. (2016). Influential factors on preservice teachers' intentions to use ICT in future lessons. Computers in Human Behavior, 56, 170-178. doi:10.1016/j.chb.2015.11.030

Baydas, O., \& Yilmaz, R. M. (2018). Pre-service teachers' intention to adopt mobile learning: A motivational model. British Journal of Educational Technology, 49(1), 137-152. doi:10.1111/bjet.12521

Beacham, N., \& McIntosh, K. (2014). Student teachers' attitudes and beliefs towards using ICT within inclusive education and practice. Journal of Research in Special Educational Needs, 14(3), 180-191. doi:10.1111/1471-3802.12000

Blackley, S., \& Walker, R. (2017). Pre-service teachers' reflections: The influence of school 1: 1 laptop programs on their developing teaching practice. Australian Journal of Teacher Education (Online), 42(2), 1.

Bower, M., Highfield, K., Furney, P., \& Mowbray, L. (2013). Supporting pre-service teachers' technology-enabled learning design thinking through whole of programme transformation. Educational Media International, 50(1), 39-50. doi:10.1080/09523987.2013.777183

Bratina, T. (2017). The Appeal and Applicability of ICT Study Materials - The Viewpoint of Generation-Z Pre-Service Teachers. Zanimivost in uporabnost študijskih vsebin IKT vidikbodoèih uèiteljev generacije Z., 10(1), 115-126.

Braun, V., \& Clarke, V. (2006). Using thematic analysis in psychology. Qualitative research in psychology, 3(2), 77-101.

Brun, M., \& Hinostroza, J. E. (2014). Learning to become a teacher in the 21st century: ICT integration in Initial Teacher Education in Chile. Journal of Educational Technology \& Society, 17(3), 222.

Chen, R.J. (2010). Investigating models for preservice teachers' use of technology to support student-centered learning. Computers \& Education, 55(1), 32-42.

Chitiyo, R., \& Harmon, S. W. (2009). An analysis of the integration of instructional technology in pre-service teacher education in Zimbabwe. Educational Technology Research \& Development, 57(6), 807-830. doi:10.1007/s11423-009-9136-7

Elstad, E., \& Christophersen, K.-A. (2017). Perceptions of Digital Competency among Student Teachers: Contributing to the Development of Student Teachers' Instructional SelfEfficacy in Technology-Rich Classrooms. Education Sciences, 7(1), 1-15. doi:10.3390/educsci7010027

Gill, L., \& Dalgarno, B. (2017). A qualitative analysis of pre-service primary school teachers' TPACK development over the four years of their teacher preparation programme. Technology, pedagogy and education, 26(4), 439-456. doi:10.1080/1475939x.2017.1287124

Gill, L., Dalgarno, B., \& Carlson, L. (2015). How Does Pre-Service Teacher Preparedness to Use ICTs for Learning and Teaching Develop Through Their Degree Program? Australian Journal of Teacher Education, 40(40). doi:10.14221/ajte.2015v40n1.3

Gudmundsdottir, G. B., \& Hatlevik, O. E. (2017). Newly qualified teachers' professional digital competence: implications for teacher education. European Journal of Teacher Education, 1-17. doi:10.1080/02619768.2017.1416085 
Guo, R. X., Dobson, T., \& Petrina, S. (2008). Digital natives, digital immigrants: An analysis of age and ICT competency in teacher education. Journal of Educational Computing Research, 38(3), 235-254.

Gyamfi, S. A. (2017). Pre-service teachers' attitude towards information and communication technology usage: A Ghanaian survey. International Journal of Education \& Development using Information \& Communication Technology, 13(1), 52-69.

Hofer, M., \& Grandgenett, N. (2012). TPACK development in teacher education: A longitudinal study of preservice teachers in a secondary MA Ed. program. Journal of Research on Technology in Education, 45(1), 83-106.

Hope, J. K., \& Hunt, A. N. (2010). Changes to the Information and Communication Technology Skills of Pre-Service Teachers Over Time. Ubiquitous Learning: An International Journal, 2(4), 1-9.

Instefjord, E. (2015). Appropriation of digital competence in teacher education. Nordic Journal of Digital Literacy, 10(Jubileumsnummer), 155-171.

Instefjord, E., \& Munthe, E. (2015). Preparing pre-service teachers to integrate technology: an analysis of the emphasis on digital competence in teacher education curricula. European Journal of Teacher Education, 39(1), 77-93. doi:10.1080/02619768.2015.1100602

Instefjord, E., \& Munthe, E. (2017). Educating digitally competent teachers: A study of integration of professional digital competence in teacher education. Teaching and Teacher Education, 67, 37-45. doi:10.1016/j.tate.2017.05.016

Jamieson-Proctor, R., Finger, G., \& Albion, P. (2010). Auditing the TK and TPACK confidence of pre-service teachers: Are they ready for the profession? Australian Educational Computing, 25(1), 8-17.

Kabakci Yurdakul, I., \& Çoklar, A. N. (2014). Modeling preservice teachers' TPACK competencies based on ICT usage. Journal of Computer Assisted Learning, 30(4), 363376.

Kaufman, K. (2015). Information communication technology: challenges \& some prospects from preservice education to the classroom. Mid-Atlantic Education Review.

Koh, J., Woo, H.-L., \& Lim, W.-Y. (2013). Understanding the relationship between Singapore preservice teachers' ICT course experiences and technological pedagogical content knowledge (TPACK) through ICT course evaluation. Educational Assessment, Evaluation \& Accountability, 25(4), 321-339. doi:10.1007/s11092-013-9165-y

Krumsvik, R. J. (2011). Digital competence in the Norwegian teacher education and schools. Högre utbildning, 1(1), 39-51.

Krumsvik, R. J. (2012). Teacher educators' digital competence. Scandinavian Journal of Educational Research, 58(3), 269-280. doi:10.1080/00313831.2012.726273

Kumar, S., \& Vigil, K. (2011). The net generation as preservice teachers: Transferring familiarity with new technologies to educational environments. Journal of Digital Learning in Teacher Education, 27(4), 144-153.

Lips, M., Eppel, E., McRae, H., Starkey, L., Sylvester, A., Parore, P., \& Barlow, L. (2017). Understanding children's use and experience with digital technologies Final research report. Retrieved from: https://www.victoria.ac.nz/ data/assets/pdf file/0003/960177/Understandingchildren-use-and-experience-of-digital-technologies-2017-v2.pdf

Maderick, J., Zhang, S., Hartley, K., \& Marchand, G. (2016). Preservice Teachers and SelfAssessing Digital Competence. Journal of Educational Computing Research, 54(3), 326351. doi:10.1177/0735633115620432

Margaryan, A., Littlejohn, A., \& Vojt, G. (2011). Are digital natives a myth or reality? University students' use of digital technologies. Computers \& Education, 56(2), 429-440. doi:https://doi.org/10.1016/i.compedu.2010.09.004 
Martinovic, D., \& Zhang, Z. (2012). Situating ICT in the teacher education program: Overcoming challenges, fulfilling expectations. Teaching and Teacher Education, 28(3), 461-469.

Mishra, P., \& Koehler, M. J. (2006). Technological pedagogical content knowledge: A framework for teacher knowledge. Teachers College Record, 108(6), 1017.

Mukama, E. (2009). The interplay between learning and the use of ICT in Rwandan student teachers' everyday practice. Journal of Computer Assisted Learning, 25(6), 539-548. doi:10.1111/j.1365-2729.2009.00326.x

Peeraer, J., \& Van Petegem, P. (2011). ICT in teacher education in an emerging developing country: Vietnam's baseline situation at the start of 'The Year of ICT'. Computers \& Education, 56(4), 974-982.

Ping, G., Tan, S. C., Longlong, W., Wong, A., \& Choy, D. (2011). Self reflection and preservice teachers' technological pedagogical knowledge: Promoting earlier adoption of student-centred pedagogies. Australasian Journal of Educational Technology, 27(6), 997-1013.

Polly, D., Mims, C., Shepherd, C. E., \& Inan, F. (2010). Evidence of impact: Transforming teacher education with preparing tomorrow's teachers to teach with technology (PT3) grants. Teaching and Teacher Education, 26(4), 863-870.

Prensky, M. (2001). Digital natives, digital immigrants part 1. On the horizon, 9(5), 1-6.

Reyes, V. C., Reading, C., Doyle, H., \& Gregory, S. (2017). Integrating ICT into teacher education programs from a TPACK perspective: Exploring perceptions of university lecturers. Computers \& Education, 115, 1-19. doi:10.1016/j.compedu.2017.07.009

Røkenes, F. M., \& Krumsvik, R. J. (2014). Development of Student Teachers' Digital Competence in Teacher Education-A Literature Review. Nordic Journal of Digital Literacy, 9(04), 250-280.

Shah, M. (2014). Impact of Management Information Systems (MIS) on School Administration: What the Literature Says. Procedia - Social and Behavioral Sciences, 116, 2799-2804. doi:https://doi.org/10.1016/j.sbspro.2014.01.659

Shinas, V. H., Karchmer-Klein, R., Mouza, C., Yilmaz-Ozden, S., \& J. Glutting, J. (2015). Analyzing Preservice Teachers' Technological Pedagogical Content Knowledge Development in the Context of a Multidimensional Teacher Preparation Program. Journal of Digital Learning in Teacher Education, 31(2), 47-55. doi:10.1080/21532974.2015.1011291

Starkey, L. (2010). Teachers' pedagogical reasoning and action in the digital age. Teachers and Teaching: theory and practice, 16(2), 233-244.

Starkey, L. (2016). An equitable curriculum for a digital age. Curriculum Matters, 12, 29-45.

Starkey, L., \& Eppel, E. (2017). Digital data in New Zealand schools: Policy reform and school leadership. Educational management administration \& leadership, 1741143217745881. doi:10.1177/1741143217745881

Tondeur, J., Aesaert, K., Pynoo, B., Braak, J., Fraeyman, N., \& Erstad, O. (2017). Developing a validated instrument to measure preservice teachers' ICT competencies: Meeting the demands of the 21st century. British Journal of Educational Technology, 48(2), 462472.

Tondeur, J., Pareja Roblin, N., van Braak, J., Voogt, J., \& Prestridge, S. (2016). Preparing beginning teachers for technology integration in education: ready for take-off? Technology, pedagogy and education, 26(2), 157-177. doi:10.1080/1475939x.2016.1193556

Tondeur, J., Roblin, N. P., van Braak, J., Fisser, P., \& Voogt, J. (2013). Technological pedagogical content knowledge in teacher education: In search of a new curriculum. Educational Studies, 39(2), 239-243.

Tondeur, J., Scherer, R., Siddiq, F., \& Baran, E. (2017). A comprehensive investigation of TPACK within pre-service teachers' ICT profiles: Mind the gap! Australasian Journal of Educational Technology, 33(3), 46-60. 
Turvey, K. (2008). Student teachers go online; the need for a focus on human agency and pedagogy in learning about 'e-learning' in initial teacher education (ITE). Education \& Information Technologies, 13(4), 317-327. doi:10.1007/s10639-008-9072-x

Urbani, J. M., Roshandel, S., Michaels, R., \& Truesdell, E. (2017). Developing and Modeling 21st-Century Skills with Preservice Teachers. Teacher Education Quarterly, 44(4), 2750.

Valtonen, T., Kukkonen, J., Kontkanen, S., Mäkitalo-Siegl, K., \& Sointu, E. (2018). Differences in pre-service teachers' knowledge and readiness to use ICT in education. Journal of Computer Assisted Learning. doi:10.1111/jcal.12225

Valtonen, T., Kukkonen, J., Kontkanen, S., Sormunen, K., Dillon, P., \& Sointu, E. (2015). The impact of authentic learning experiences with ICT on pre-service teachers' intentions to use ICT for teaching and learning. Computers \& Education, 81, 49-58.

Voogt, J., Fisser, P., Pareja Roblin, N., Tondeur, J., \& van Braak, J. (2013). Technological pedagogical content knowledge-a review of the literature. Journal of Computer Assisted Learning, 29(2), 109-121.

Xiong, X., \& Lim, C. (2015). Curriculum Leadership and the Development of ICT in Education Competencies of Pre-service Teachers in South China. Asia-Pacific Education Researcher (Springer Science \& Business Media B.V.), 24(3), 515-524. doi:10.1007/s40299-015-0238-1

Yeung, A. S., Lim, K. M., Tay, E. G., Lam-Chiang, A. C., \& Hui, C. (2012). Relating use of digital technology by pre-service teachers to confidence: A Singapore survey. Australasian Journal of Educational Technology, 28(8). 